\title{
"LA BELLA CRIMINAL QUE MATÓ POR AMOR". JUSTICIA, HONOR FEMENINO Y ADULTERIO (CIUDAD DE MÉXICO, DÉCADA DE 1930)
}

\author{
"La bella criminal que mató por amor". \\ Justice, feminine honor and adultery \\ (Mexico City, 1930's)
}

Elisa Speckman Guerra*

\begin{abstract}
RESUMEN
En este capítulo analizo el caso de Concetta di Leone, quien en 1936 asesinó a su marido. El crimen atrajo la atención de la prensa y dio lugar a un relato propio de una novela romántica. Su abogado defensor justificó el homicidio en razón del adulterio cometido por el cónyuge, sea argumentando que ella había actuado en defensa legítima del honor o considerando que había matado en un estado de profunda perturbación sicológica generado por el descubrimiento del engaño. El análisis de ambas figuras normativas y de las sentencias emitidas por los jueces resulta interesante. El asunto permite estudiar temas como la vinculación de la ley con ideas y con valores, o el margen de decisión de los jueces y los factores que influían en sus decisiones. En general, permite adentrarse en el debate sobre cómo debía funcionar la justicia y quienes debían impartirla, debate importante en la época, pues recientemente se había suprimido el juicio por jurado y se había optado por una justicia impartida exclusivamente por jueces formados en el derecho. Aún más, los argumentos de los actores que intervinieron en el juicio, de los juristas y de los periodistas, abren la posibilidad de asomarse a temas como la concepción del honor, de la mujer y del amor.
\end{abstract}

Palabras-clave: justicia; honor femenino; derecho penal

* Instituto de Investigaciones Históricas UNAM - Instituto Nacional de Ciencias Penales. E-mail de contato: speckman@unam.mx 


\begin{abstract}
In this chapter, I discuss the case of Concetta di Leone, who in 1936 murdered her husband. The crime drew the attention of the press and led to a narrative of a novel. Her defense attorney justifies the murder for adultery committed by the spouse, arguing that she either acted in self defense of honor or considering she had killed him in a state of profound psychological disturbance caused for finding out about the betrayal. The analyses of both normative figures and the statements issued by the judges have an interesting result. The subject allows studying topics such as linking law with ideas and values, or the margin of decision of the judges and the factors influencing their decisions. In general, it allows to enter the debate on how justice should work and who it should confer important debate at that time, because trial by jury had recently been abolished and justice determined exclusively by judges graduated in Law was the actual option. Moreover, the arguments of the actors who participated in the trial, lawyers and journalists, open the possibility of an approach to issues such as the concept of honor, women and love.
\end{abstract}

Keywords: justice; feminine honor; criminal law

En 1936 Concetta di Leone asesinó a su marido, un príncipe ruso, en una plaza de la Ciudad de México. ${ }^{1}$ El crimen no sólo podría haber servido como inspiración para una novela, del crimen se construyó una novela. La prensa, la princesa y su abogado hilaron un relato romántico, propio del ambiente imperante en la época de la postguerra mundial y de la postrevolución mexicana.

¿Cómo influyó este relato en las decisiones de los jueces de Concetta di Leone y qué pieza agregaron los juzgadores a esta novela colectiva? Hablo de pieza, no de desenlace, pues las consideraciones emitidas por los jueces, y que fueron comentadas por periodistas y por el defensor de la procesada, contribuyeron en la construcción de la imagen de la criminal y de su crimen. Así, el dibujo de la homicida trazado de forma previa al juicio posiblemente influyó en la decisión

1 Un breve acercamiento a este caso, comparado con el de otra homicida, Nydia Camargo, puede verse en el capítulo "Dos autoviudas (1925 y 1936)", en SPECKMAN GUERRA, Elisa, Del Tigre de Santa Julia, la princesa italiana y otras historias. Sistema judicial, criminalidad y justicia en la Ciudad de México (siglos XIX y XX), México, Instituto Nacional de Ciencias Penales-Instituto de Investigaciones Históricas UNAM, 2014, pp. 201-215. 
de sus juzgadores quienes, con sus consideraciones, reafirmaron o modificaron los trazos.

La pregunta planteada al inicio del párrafo anterior constituye una de las inquietudes presentes en el trabajo. No es la única, pues el caso abre interrogantes relativas a varios temas: la concepción de la mujer, del honor en general y del honor femenino en particular, y de la pareja; la legislación y su vinculación con códigos de conducta y de valores; el sistema de justicia y su impartición; y el peso de la opinión pública en sentencias judiciales.

¿Se consideraba que el adulterio empañaba el honor del cónyuge engañado $\mathrm{y}$, por ende, el asesinato del adúltero $\mathrm{y} / \mathrm{o}$ de su amante podía ser interpretado como una acción en defensa del honor? Adentrándonos en el honor femenino, ¿se creía que la esposa engañada también veía afectada su imagen pública y se justificaba que matara en nombre del honor mancillado? Si se desvinculaban adulterio y deshonor, ¿el asesinato del cónyuge adúltero se justificaba con otros argumentos? Las respuestas a las preguntas anteriores dependen de la concepción de la mujer, de la pareja y del amor, y por ende, cambian según la época y el lugar, el sector social y cultural al que pertenece el individuo que las responde o incluso el individuo que les da respuesta. En general, creo importante preguntarse: ¿el cambio en la situación y la concepción de la mujer que, según diversos historiadores, se registró tras la Revolución, conlleva una variación en la visión sobre la esposa víctima del adulterio y sobre las reacciones que se justificaban en reacción a dicha ofensa?

También resultan interesantes las preguntas que el proceso permite plantear en torno a las normas que regulaban al uxoricidio por adulterio y su vinculación con ideas y valores.

Por último, el caso permite plantear preguntas relevantes en torno a las consecuencias que un reciente cambio en el sistema de justicia pudo tener en la nota roja y, sobre todo, en la resolución de los casos. En 1929 se suprimió el juicio por jurado y se produjo el tránsito de una justicia mixta (en que participaban jurados o ciudadanos legos) a una justicia impartida por jueces profesionales. Diversos argumentos sustentaron la supresión, entre otras cosas, se dijo que los miembros del jurado no emitían su veredicto basándose exclusivamente en las pruebas presentadas sino influidos por simpatías, antipatías, prejuicios, expectativas, temores, fantasías, 
imaginarios, etcétera. Las absoluciones de varias mujeres que en la década de 1920 mataron a sus esposos o amantes permitieron a los detractores del tribunal sustentar esta idea. ${ }^{2}$ Se decía, en suma, que los jueces profesionales se apegarían a las pruebas y a las leyes. Considerando lo anterior, cabe preguntarse: ¿la opinión pública, favorable a la princesa, hubiera tenido más peso en los jueces legos que en los profesionales? ¿La suerte de Concetta di Leone habría sido diferente si hubiera matado siete años antes y hubiera sido juzgada por nueve ciudadanos?

Así, el caso no sólo permite plantear preguntas sobre varios temas sino que se vincula con interesantes procesos, como el cambio de valores registrado a principios del siglo XX, el paso de una prensa de nota roja centrada en el juicio a una centrada en el crimen, o el tránsito de una justicia mixta a una profesional.

Para estudiarlo utilicé archivos judiciales y periódicos. Revisé el proceso de primera y de segunda instancia, así como el expediente carcelario de Concetta di Leone. Asimismo, revisé tres periódicos de amplia difusión: Excélsior y dos más inclinados a la nota roja, El Universal Gráfico (edición vespertina de El Universal) y La Prensa.

Lo anterior me permite relatar, primero, la historia de la criminal y de su crimen. Tras el relato, presentaré el escenario del juicio, considerando el sistema de justicia y los actores que intervenían en su impartición, la legislación aplicable al homicidio cometido por adulterio y experiencias de homicidas que en la etapa del juicio por jurado argumentaron haber matado en defensa de su honor. Finalmente, daré noticia del desenlace, considerando decisiones de los jueces y la visión que de su futuro presentó Concetta di Leone, viuda del príncipe Nigeradze.

2 Para el juicio por jurado y los argumentos esgrimidos en favor y en contra de la institución, ver "El jurado popular para delitos comunes: leyes, ideas y prácticas (1869-1929)", en SPECKMAN GUERRA, Elisa, Del Tigre de Santa Julia, la princesa italiana y otras historias. Sistema judicial, criminalidad y justicia en la Ciudad de México (siglos XIX y XX), Op. Cit, pp. 93 128. 


\section{El drama}

"Recibí la visita de un príncipe, me dijo que tú y él están enamorados, que quieres el divorcio". ${ }^{3}$ Esas fueron las palabras que Juan de Velasco le dirigió a su esposa el día en que fue visitado en su oficina, la jefatura de compras de los ferrocarriles mexicanos, por Vladimir Nigeradze. Ella lo confirmó y poco después se separó de su marido, con quien tenía 13 años de casada y dos hijos. Inmediatamente contrajo matrimonio con el ruso.

Vladimir Nigeradze (Nizharadz) se ostentaba como descendiente de una familia georgiana que se contaba entre las principales ramas nobles de Rusia a mediados del siglo XIX. Muchos de sus miembros, entre ellos Vladimir, sirvieron en los ejércitos del zar. Sin embargo, al triunfo de la revolución soviética debieron salir del país, dejando atrás su fortuna y sus privilegios.

Concepción, proveniente de una familia de origen italiano, era culta y muy bella. No tuvo problemas para adaptarse al grupo social que frecuentaba su marido ni a las obligaciones sociales derivadas de su título: la princesa Nigeradze. Tras casarse viajaban frecuentemente a Europa y, estando en México, ella tomaba clases de equitación y de tiro.

La costosa forma de vida minaba el patrimonio que Concetta di Leone había recibido de su marido y su familia. Ello sin contar el dinero invertido en los negocios de Vladimir Nigeradze, entre ellos, una fábrica de jabón. Con el tiempo la flamante princesa perdió su dinero, a sus hijos y a su marido, quien se mudó a un hotel pero comía diariamente en la casa del cónsul de Finlandia, Leo Granroos. Al parecer se hizo amante de su cónyuge, Xenia Prochorova. "Esa mujer tiene la culpa de todo; ella fue la que me arrebató el cariño y la consideración de mi esposo", relataría posteriormente Concetta di Leone a periodistas y agentes investigadores. ${ }^{4}$

3 Tomado de GARMABELLA, José Ramón, ¡Reportero de policia! El Güero Téllez, México, Editorial DeBolsillo, 1982, p. 185.

4 "Un príncipe asesinado por su esposa en el Hipódromo", La Prensa, 29 de noviembre de 1936 , p. 30. 
Sola y sin dinero, pasaba horas persiguiendo al hombre que la había dejado. Las escenas en que imploraba su amor y le manifestaba sus celos fueron presenciadas y posteriormente relatadas por varios testigos. Por ejemplo, una noche, cuando Vladimir Nigeradze salía del cine acompañado por los Granroos, Concetta di Leone le golpeó la cara con su bolso, él le detuvo la mano con tal violencia que le luxó un dedo. Cada vez más trastornada, ella se apostó permanentemente fuera del edificio que habitaba el marido: "Me conformaba con verlo salir. Una criada compadecida me hacía compañía y a ella le confiaba mis pesares".

No sólo esperaba verlo salir, también esperaba la oportunidad de delatarlo con el diplomático, pues confiaba en que si éste constataba la infidelidad de su esposa le pediría a Vladimir que abandonara su casa. Una tarde, vio al ruso introducirse furtivamente a la casa de Xenia Prochorova. Le avisó al esposo de ella, quien poco después llegó a la vivienda. Esperó un largo rato y nada sucedía. Entonces se dirigió a la caseta telefónica más cercana para marcar al domicilio de los Gronroos y, de nueva cuenta, hablar con Leo. Le suplicó que intercediera por ella. "No puedo hacer nada, por lo que veo lo que usted pretende es seguir ostentando el título de princesa". Después le comunicaron a Vladimir. "Mira, lindo, es preciso que vuelvas a mi lado, pues la vida es imposible para mi si no estás conmigo". Éste le respondió: "Es mejor que me olvides pues tengo el firme propósito de no volver a tu lado jamás" y sugirió que "siguiera la línea" de muchas señoras, cuyos maridos tenían amantes sin que ellas se molestaran. ${ }^{5}$

5 Para el relato del matrimonio de Concetta di Leone y los sucesos registrados antes del homicidio pueden verse el auto de formal prisión dictado por el juez en su expediente carcelario (Archivo Histórico del Distrito Federal, Fondo Cárceles, Penitenciaría, Expedientes de reos 19201949, Caja 331, Partida 6408) y el proceso de primera instancia, publicado en Anales de Jurisprudencia, Año 1937, Tomo XIX, pp. 693-698. El mismo relato puede verse en las notas periodísticas publicadas en los tres periódicos revisados: Excélsior ("Príncipe asesinado. Honda tragedia en la glorieta de Citlaltepetl", 29 de noviembre de 1936, Segunda Sección, p. 7; "Bella princesa en el escuadrón de la muerte. Nadie ha pedido el cadáver del noble Nigeradse", 30 de noviembre de 1936, Segunda sección, p. 8; "Concetta di Leone fue informada ya sobre la muerte del príncipe", 1 de diciembre de 1936, Segunda Sección, p. 6 y "Concetta di Leone quiere morir", 1 de diciembre de 1936, Segunda Sección, p. 8); El Universal Gráfico ("La princesa ignora o finge ignorar que es una homicida. Su relato en la reja del juzgado", 1 de diciembre de 1936, pp. 3 y18); y La Prensa ("Dolorosa historia de Concetta, la bella criminal que mató por amor", 1 de diciembre de 
Conceta di Leone se dirigió a su casa y tomó una pistola calibre 32 que el ruso le había regalado. Regresó a la puerta del edificio esperando que éste saliera a caminar, como lo hacía todas las tardes acompañado por el cónsul. En la plaza de Citlaltépetl, en la colonia Hipódromo - Condesa, le disparó cuatro tiros. "Chula, volveré a ti, volveré a ti", dijo Vladimir Nigeradze antes de perder la consciencia. "Lindo, óyeme, te he querido con delirio, te amo con toda la vida, ¿verdad que aún me quieres?", fueron las últimas que ella le dirigió. Los testigos la desarmaron antes de que pudiera suicidarse. $^{6}$

Vladimir Nigeradze murió camino al hospital, Concetta di Leone sufrió una crisis nerviosa en su tránsito a la Delegación de Policía. La inculpada permaneció en ese estado por muchas horas, ignoraba que su marido había muerto y soñaba con que la visitaba llevando un gran ramo de rosas. ${ }^{7}$ Tres días después, cuando ya había sido trasladada a la penitenciaria de Lecumberri, donde estaría presa de forma preventiva mientras transcurría su juicio, la jefa de celadoras le dio la noticia. "Lo que se esperaba ocurrió, llantos, gritos y estallidos de nervios", relató el reportero de Excélsior. ${ }^{8}$

Los periódicos y el público simpatizaron con la homicida. Los primeros, reprodujeron los detalles de la historia anteriormente relatada. Para ese entonces la nota roja había dejado de centrarse en el juicio como lo hacía en la etapa en que funcionaba el jurado, en los años en que la sala de audiencias se abarrotaba de un público ansioso de presenciar la actuación de los testigos y de los peritos, de conocer a los procesadas y de escuchar las larguísimas intervenciones del fiscal y del defensor. Ahora se centraba en el crimen. Los reporteros como Alberto Téllez Vázquez "El "Güero Téllez", quien cubrió el caso - eran avisados por la policía y se presentaban aún antes que los

1936, p. 15 y "La princesa Concetta se debate en una intriga que será un escándalo social”, 2 de diciembre de 1936, pp. 2 y 17).

6 Para el relato del crimen ver "Príncipe asesinado. Honda tragedia en la glorieta de Citaltepetl", Excélsior, 29 de noviembre de 1936, Segunda Sección, p. 1; y "Un príncipe asesinado por su esposa en el Hipódromo", La Prensa, 29 de noviembre de 1936, pp. 3 y 30. 1936, p. 17.

7 "La bella princesa que nada quiere y nada espera", La Prensa, 30 de noviembre de

8 "Concetta di Leone fue informada ya sobre la muerte del príncipe", Excélsior, 1 de diciembre de 1936, Segunda Sección, p. 1; y "La princesa Concetta se debate en una intriga que será un escándalo social”, La Prensa, 2 de diciembre de 1936, pp. 2 y 17. 
detectives en la escena del crimen, participaban en la investigación y daban detallada cuenta de sus progresos. Una vez iniciado el proceso las noticias escaseaban, pues ni las diligencias breves ante las rejas ni las conclusiones que por escrito presentaban los litigantes resultaban atractivas.

Interesados por los detalles del crimen y los móviles de la protagonista, los periodistas publicaron y adornaron la declaración rendida por Concetta di Leone ante la policía y ante su juez, además de publicar una carta que ella supuestamente había escrito a Vladimir días antes de matarlo.

"Por este hombre abandoné a aquél otro, que fue muy bueno para mí y me quiso mucho". Con el divorcio inició una historia que Concetta di Leone narraría con mayor detalle, la de su segundo matrimonio. "Como conviene a una buena esposa, fui buena y sufrida para él, jamás le fui infiel, ni con el pensamiento". Sostuvo que había vendido su casa y sus joyas para ayudar a Vladimir Nigeradze en sus proyectos y que le había entregado todo su dinero, incluyendo catorce mil pesos para su fábrica. Lamentó que, a pesar de ello, él la hubiera dejado sola cuando estaban en la miseria. ${ }^{9}$

Lo responsabilizó de sus padecimientos económicos: “Tú pagas 60 pesos mensuales, por alimentos, en cambio no tuviste dinero para darme y yo, desesperada, tuve que buscar dinero prestado para poder comer". Y lo culpó de su soledad: "Por él he sido abandonada de mis dos hijos, que se me han desamorado y ya no me quieren". Le escribió:

lo que más me desespera en mi vida contigo, es que te acuerdes de que hace tres años, estando con mis hijos jugando en nuestra casa y teniendo el niño trece años de edad, tu bajaste a la sala al oír que hacían ruido los dos hermanitos y lejos de hacerles algunas observaciones como todo hombre correcto, le diste un bofetón al niño en la cara, hinchándosela y poniéndosela morada, claro, el niño al ver eso y sin poderse defender, porque era my

9 "Príncipe asesinado. Honda tragedia en la glorieta de Citaltepetl", Excélsior, 29 de noviembre de 1936, Segunda Sección, p. 7. 
chiquito, tomó a su hermanita y se fue para casa de su abuelita, sin jamás volver a entrar a mi casa.

Para, finamente, preguntarse: “¿Cómo voy a quedar conforme en estar así, sola, abandonada, sin dinero, sin el amor de mis hijos, con un hogar perdido, en fin, en la miseria, desgraciada y en la calle". ${ }^{10}$

Por lo general, el seguimiento que los periódicos realizaban del crimen estaba acompañado con por fotografías y fotomontajes, en los cuales la imagen del inculpado se colocaba junto a la del cadáver de la víctima o la escena del crimen. Como afirma la historiadora Rebeca Monroy, en esa época mejoró la técnica fotográfica y se redujo el tamaño de las cámaras, lo cual permitió a los reporteros cubrir mayor gama de sucesos, además se introdujo el fotograbado con lo que se facilitó la reproducción de imágenes en los periódicos. ${ }^{11}$ En palabras de otro historiador, Pablo Piccato, "surgió un lenguaje gráfico que llenaba las planas de los diarios con imágenes de cadáveres desnudos o en estado de composición, junto a retratos policiacos de los sospechosos, así como de los instrumentos y evidencias de la muerte". Las imágenes conferían un matiz dramático a los reportajes escritos y el color de la sangre daba su nombre a la "nota roja". 12

Sin embargo, en este caso prácticamente no hubo imágenes. Los protagonistas prefirieron no ser fotografiados y al parecer contaron con las influencias que les permitieron evitarlo. Tampoco Concetta quería ser fotografiada. “ ¡Ahora no me podrán sacar la cara, pues no me quitaré el chal", les dijo a los reporteros que la esperaban en las rejas del juzgado y se cubrió con un grueso chal de punto y un

10 "Una carta de Concetta, la bella matadora del príncipe destila amor, odios, penas y venganzas", La Prensa, 10 de abril de 1937, pp. 2 y 19.

11 MONROY NASR, Rebeca, Historias para ver. Enrique Díaz, fotorreportero, México, Instituto de Investigaciones Estéticas, Universidad Nacional Autónoma de México Instituto Nacional de Antropología e Historia, 2003.

12 PICCATO, "Todo homicidio es político. El asesinato en la esfera pública en el México del siglo XX”, en Víctor GAYOL, Formas de gobierno en México. Poder político y actores sociales a través del tiempo. Volumen II: Poder político en el México moderno y contemporáneo, Zamora, El Colegio de Michoacán, 2012 (Colección Debates), pp. 627-654. La cita en pp. 635-636. 
abrigo. ${ }^{13}$ La princesa había tenido mejores tiempos y había sido fotografiada en mejores condiciones. No debía aprovechar la oportunidad de ser captada por las cámaras, como debieron hacerlo criminales que sólo tras matar alcanzaron la fama, como María Elena Blanco.

La renuencia a acceder a las pretensiones de los fotógrafos no minó la simpatía que le profesaban los redactores. Excélsior se refirió a ella como "la hermosa matadora que obró en un momento de loca ofuscación" o como "la princesa de los tristes destinos", La Prensa habló de "la bella criminal que mató por amor". ${ }^{14}$

También los lectores mostraron inclinación hacia la inculpada. Le surgieron enamorados. Uno de ellos, Kid Guerrero, boxeador y empresario boxístico, le ofreció su apoyo y su apellido:

Muy estimada y linda princesa, tengo el gusto de saludarla muy cariñosamente y ponerme a sus pies en cuerpo y alma para lo que desee y tengo el placer de decirle que muy pronto puedo servirla y dar mi vida y hasta mi trabajo por usted. Perdone mi franqueza y mi discreción, pero es que la quiero a usted con toda mi alma desde el primer día en que la vi ... Ya puede usted olvidar sus penas pues hay un corazón que la adora. ${ }^{15}$

Así, Concetta di Leone quedaba convertida en un personaje de novela romántica, como correspondía a la época en que Eduardo VIII de Inglaterra abdicaba al trono por su amor a una divorciada estadounidense, Wallis Simpson. A ella le gustaba la similitud, se trataba de dos plebeyas casadas con dos príncipes.

13 "La princesa ignora o finge ignorar que es una homicida. Su relato en la reja del juzgado", El Universal Gráfico, 1 de diciembre de 1936, p. 3.

14 Excélsior, "Príncipe asesinado. Honda tragedia en la glorieta de Citaltepetl", 29 de noviembre de 1936, Segunda Sección, p. 9; y "Concetta di Leone quiere morir", 1 de diciembre de 1936, Segunda Sección, p. 1; y La Prensa, "Dolorosa historia de Concetta, la bella criminal que mató por amor", 1 de diciembre de 1936, pp. 2, 7, 15 y 19.

15 La carta fue publicada en los diarios: "Un boxeador se ha enamorado locamente de la bella princesa", La Prensa, 11 de diciembre de 1936, pp. 2 y 17. 


\section{El escenario}

En la década de 1930 los homicidios eran juzgados por Cortes Penales. ${ }^{16}$ Dichos tribunales fueron creados en 1929 para sustituir al jurado popular y estaban integrados por tres jueces, quienes al ocupar el cargo debían estar formados en el derecho y contar con experiencia previa. Por tanto, se ofrecía una justicia colegiada y profesional.

El proceso se dividía en dos fases: instrucción y audiencia. En la primera, dirigida por uno de los jueces que integraban la Corte Penal, el agente del Ministerio Público y el defensor presentaban pruebas tendientes a determinar la forma en que había ocurrido el hecho juzgado. Los tres jueces asistían a la vista de la causa. Una vez que presentaban sus posturas, la acusación y la defensa cuestionaban al procesado, testigos y peritos, buscando que los jueces tuvieron contacto con las pruebas. La audiencia concluía con los alegatos. ${ }^{17} \mathrm{De}$ acuerdo al sistema de justicia - mixto, pero con ingredientes importantes del acusatorio - el fiscal y el defensor debían estar en igualdad de condiciones.

El juez que se había encargado de la instrucción elaboraba un proyecto de sentencia, que sometía al voto de sus compañeros. Con base en las pruebas, los jueces determinaban la responsabilidad del procesado y las circunstancias del delito, para finalmente determinar el tipo penal correspondiente y gradar la pena. Según ordenaba la Constitución, ningún individuo podía ser juzgado con leyes retroactivas que lo perjudicaran y sólo se le podía imponer una pena decretada por una ley exactamente aplicable al delito cometido. ${ }^{18}$ En el código penal se enlistaban las acciones que podían ser consideradas como delito y se contemplaba la pena que cada una merecía. En el caso de la prisión se fijaba un límite temporal. Con el fin de gradar la

16 Las Cortes Penales conocían de los delitos que merecían una pena media mayor a seis meses de prisión. Código de procedimientos penales para el Distrito y Territorios Federales promulgado el 2 de enero de 1931 (en adelante Código de procedimientos penales de 1931), art. 10.

17 Código de procedimientos penales de 1931, arts. 287-304 y 313-331.

18 Constitución Política de los Estados Unidos Mexicanos promulgada en 1917 (en adelante Constitución de 1971), art. 14. 
sanción dentro del máximo y el mínimo, los jueces podían considerar libremente tanto las circunstancias en que se había cometido el delito como las características del criminal. ${ }^{19}$

Una vez notificada la decisión, si la acusación o la defensa consideraban que en el procedimiento se habían violado leyes procesales o en la sentencia leyes de fondo, podían apelar. El recurso era revisado por el Tribunal Superior de Justicia del Distrito Federal (en adelante TSJ), cuyas salas también funcionaban de forma colegiada. Los Magistrados podían confirmar, revocar o modificar la resolución de primera instancia. Su decisión era definitiva. ${ }^{20}$ No obstante, el sentenciado podía interponer una demanda de amparo si consideraba que las autoridades judiciales habían violado sus derechos consagrados en la Constitución (no sólo derechos procesales, también el artículo que ordenaba la exacta aplicación de la ley). ${ }^{21}$ El juicio de amparo estaba a cargo de tribunales federales.

En suma, los jueces debían respetar los principios constitucionales y ceñirse a las leyes penales. No estaban obligados a observar los criterios de los Ministros (a menos que hubieran generado jurisprudencia) ni de los Magistrados. Sin embargo, según juristas de la época, sus tesis sí eran tomadas en cuenta. ${ }^{22}$ Ahora bien, como señalé arriba, el supuesto desapego de los miembros del jurado popular respecto a las pruebas presentadas al momento de determinar la responsabilidad del procesado y la forma en que había ocurrido el hecho juzgado, fue uno de los argumentos principales que se esgrimieron con objeto de suprimir al tribunal. Según los detractores del juicio por jurado, el veredicto de los ciudadanos obligaba al juez de derecho a aplicar una ley que no se ajustaba al hecho probado y, con ello, se violaba el principio de legalidad. Lo anterior, presumiblemente, dejaría de ocurrir si la justicia quedaba a cargo de

19 Código penal para el Distrito y Territorios Federales en materia de fuero común y para toda la República en materia de fuero federal, expedido el de enero de 1931 (en adelante código penal de 1931), arts.51-59.

20 Código de procedimientos penales de 1931, arts. 414-434.

21 Los derechos del inculpado y del procesado estaban contemplados en los artículos 16 - 20 de la Constitución de 1917. 31 y 33$)$.

22 Por ejemplo, Ricardo Abarca (El derecho penal en México, México, Jus, 1941, pp. 
jueces formados en el derecho y avezados en la valoración de las pruebas.

En los treintas, para el homicidio calificado (cometido con alevosía, premeditación, ventaja o traición), el código penal contemplaba una sanción que podía oscilar entre los 13 y los 20 años de prisión, para el cometido sin dichas calificativas, una sanción de entre 8 y 13 años. ${ }^{23}$ Sin embargo, tanto para el homicidio como para otros delitos, los miembros de la comisión redactora del código incluyeron figuras atenuadas y excluyentes de responsabilidad (como actuar en estado de enajenación mental permanente o transitoria, o delinquir en defensa legítima de la vida). Específicamente, al homicidio cometido en reacción al adulterio se vincularon dos figuras: el uxoricidio cometido en caso de adulterio flagrante (que merecía entre 3 días y 3 años de prisión) y la defensa legítima del honor (excluyente de responsabilidad, que derivaba en la absolución del procesado).

El análisis de estas dos figuras y de su posterior aplicación exige reflexionar sobre tres temas: el significado que en aquella época se le otorgaba al honor masculino y al femenino, la vinculación que se establecía entre el adulterio y el honor de ambos cónyuges, y por último, las acciones que se justificaban en reacción al adulterio, tanto por parte del marido como de la esposa.

En 1941, en una sentencia de amparo, sostuvieron los Ministros de la Primera Sala Penal de la Suprema Corte de Justicia de la Nación (en adelante SCJN): "Por honor debe entenderse persona sin mancha, consideración absoluta, limpieza de vida, cumplimiento absoluto del deber respecto al semejante, pundonor en no ser disminuido". ${ }^{24}$ Poco después el jurista Demetrio Sodi afirmó: "pertenece al honor lo que es decente, decoroso, razonable y justo, y vive con el honor el que no hace cosa alguna que repugne a las buenas costumbres y al decoro público o privado". ${ }^{25}$

23 Código penal de 1931, arts. 302-309 y 315-320.

24 Amparo penal directo 3549/31, fecha 21 de abril de 1933. Semanario Judicial de la Federación, Quinta época, Primera Sala, XXXVII, p. 2127. La afirmación fue retomada por los editorialistas de editorialistas de Los Tribunales, "Legítima defensa del honor", febrero de 1941, Tomo XVIII, Núm. 4, pp. 110 - 115. La cita en p. 110.

25 SODI, Demetrio, "Defensa legítima del honor", en Criminalia, 1943, Vol IX, Num. 11, pp. $681-694$. La cita en p. 682. 
Autores de la época creyeron que no se trataba meramente de la apreciación personal del individuo sobre su propia conducta, pues también contaba la opinión de la comunidad. En 1933, Clotario Margalli González, juez penal que antes había sido agente del Ministerio Público, definió al honor como "la estima y respeto de la propia dignidad y de la buena reputación personal". ${ }^{26}$ Por su parte, Demetrio Sodi lo catalogó como "la gloria o la buena reputación que sigue a la virtud, al mérito, a las acciones buenas o heroicas, las cuales trascienden a las familias, personas y acciones mismas del que se la granjea". ${ }^{27}$ Siguiendo esta idea, el penalista Mariano Ruíz Funes habló de honor subjetivo (sentimiento que poseía cada hombre de su dignidad) y objetivo (la opinión de los demás y la estima recibida en consecuencia). Consideró que ambos debían ser tutelados por las autoridades, pues formaban parte importante del patrimonio moral de una persona. ${ }^{28}$ En el mismo sentido, en 1932, Magistrados del TSJ, José Ortiz Tirado y Alfonso Teja Zabre, hablaron de un yo personal y de un yo social, y sostuvieron que los dos merecían protección jurídica, siendo la reputación un aspecto fundamental del social. ${ }^{29}$

El honor se consideraba, entonces, como un patrimonio moral que los legisladores debían proteger, sancionando a los individuos que atentaban contra la reputación de otro. Faltaba determinar si el adulterio manchaba el honor del cónyuge engañado. En relación a lo anterior se notan dos posturas: algunos consideraban que el adulterio femenino empañaba el honor del marido pero que no sucedía lo mismo con el adulterio masculino, mientras que otros creían que ni uno ni otro afectaban el honor del cónyuge engañado.

La primera corriente tenía una larga tradición. Por ejemplo, los redactores del primer código penal para el Distrito Federal, promulgado en 1871, sostuvieron: el marido queda infamado, con

26 MARGALLI GONZÁLEZ, Clotario, La excluyente de defensa del honor, México, Ediciones del Sindicato de Abogados del Distrito Federal, 1933, p. 11.

27 SODI, "Defensa legítima”, Op. Cit, p. 682.

28 RUÍZ FUNES, "El Derecho al honor", pp. 721 - 726.

29 Tomado de RUÍZ FUNES, Mariano, "El derecho al honor", Criminalia, 1944, Año X, pp. $718-733$. La cita en p. 720 . 
razón o sin ella, por la infidelidad de su consorte. ${ }^{30}$ Para la década de 1930 esta idea seguía vigente. En una tesis emitida en 1933 y que fue retomada por los editorialistas de una revista de litigantes que llevaba por título Los Tribunales, los Ministros de la Primera Sala de la SCJN, atendiendo a la "realidad ambiente, la constitución de la familia mexicana y la idea predominante en la sociedad", sostuvieron: "la esposa es la guardiana del honor conyugal y cualquier infidelidad suya, refluye directamente en el marido, lesiona su honra, mancha su vida y lo disminuye en el concepto social". ${ }^{31}$ Diez años más tarde, los Ministros de la misma Sala consideraron: "El esposo que sufre la infidelidad de su cónyuge, es objeto de las murmuraciones, de las burlas y en algunas ocasiones de las diatribas de sus vecinos, de sus conocidos y aún de extraños". Lo anterior, concluyeron, disminuía "su valor social" y dañaba su "honor externo". ${ }^{32}$

Partiendo de loa anterior, se justificaba que el marido diera muerte a los adúlteros sorprendidos in fraganti. De lo contrario, afirmó Clotario Margalli González, "será víctima al día siguiente y después, de las burlas, las críticas y las murmuraciones del público enterado de su deshonra". En su opinión, que el ofendido solicitara a los tribunales castigo para los adúlteros o tramitara el divorcio no bastaba para que la sociedad lo considerara "limpio de deshonor". Y afirmó que según el "sentir de la sociedad mexicana", en estos casos, "se hace necesaria la sangre". ${ }^{33}$ Con esta idea coincidieron los editorialistas de Los Tribunales, quienes sostuvieron que durante el tiempo que duraba el juicio subsistía una ofensa que debía haber sido atacada de forma inmediata. ${ }^{34}$

Sobra decir que esta postura también era vieja. Por ejemplo, en 1884, en defensa de un militar que había matado a su esposa adúltera, el abogado Manuel Lombardo sostuvo que un marido que se

30 "Exposición de motivos" del Código penal para el Distrito Federal y territorio de la Baja California, sobre delitos del fuero común, y para toda la República sobre delitos contra la federación, expedido en diciembre de 1871 (en adelante código penal de 1871).

31 Amparo penal directo 3549/31, fecha 21 de abril de 1933. Semanario Judicial de la Federación, Quinta época, Primera Sala, XXXVII, p. 2127.

32 Sentencia en el proceso de Ersiteo Martínez Loza, Anales de Jurisprudencia, Año 1943, Tomo XLVIII, pp. 474-476.

33 MARGALli GONZÁLEZ, La excluyente de defensa del honor, Op. Cit., pp. 15 16

34 "Legítima defensa del honor", Op. Cit, p. 112. 
encontraba en estos casos sólo podía seguir un camino digno: matar a sus ofensores. En su opinión, otros caminos no lo eran. El "desgraciado rufián que carece del valor necesario para matar" podía ignorar el asunto y convertirse en cómplice de lenocinio, o denunciarlo ante los jueces y atraerse la antipatía de la comunidad al externar "acciones que merecen sepultarse en los dolores del alma". ${ }^{35}$ En ese juicio, al igual que en otros similares, los miembros del jurado consideraron que el enjuiciado había actuado en defensa legítima del honor y determinaron su absolución.

Efectivamente, considerar que el adulterio cometido por la esposa generaba un grave daño al honor del marido, podía llevar a pensar que, al matar a los adúlteros, éste actuaba en defensa legítima de su honor. Según el código penal, actuaba en defensa de su persona, de su honor o de sus bienes, o de la persona, honor o bienes de otro, quien repelía una agresión actual, violenta, sin derecho y de la cual resultaba un peligro inminente. Ello lo eximía de responsabilidad penal y, por tanto, de sanción. La defensa legítima del honor era, entonces, equiparable a la de la vida. Pero era necesario que se presentaran varias circunstancias: que el procesado actuara en respuesta a una agresión sin derecho y que no había podido prevenir; que el peligro a su honor fuera inminente y que el daño causado no pudiera repararse posteriormente por medios legales; y que el acto defensivo fuera proporcional al daño que podía haber causado el agresor. ${ }^{36}$

Según expusieron en 1933 los Ministros de la Primera Sala en la tesis a la que aludí arriba, el homicidio de los adúlteros cometido por el marido engañado cumplía con estas condiciones. Consideraron al adulterio como una agresión actual e inminente (pues consideraban que el adulterio ofendía a los sentimientos del marido, a su honor, su fama, su estimación social, y lo entendían como un delito permanente, que no se integra por un acto carnal único), violenta

35 LOMBARDO, Manuel, Defensa pronunciada por ... en la causa instruida al teniente coronel Joaquín Morales ..., México, Imprenta de Francisco Díaz de León, 1884.

36 Código penal de 1931, art. 15, fracción III. Lo mismo en los códigos previos, el de 1871 y el de 1929. Para las consideraciones de los legisladores hacia los individuos que actuaban para defender su honor u ocultar su deshonra ver SPECKMAN GUERRA, Elisa, "De méritos y reputaciones. El honor en la ley y la justicia (Distrito Federal, 1871-1931)", Anuario Mexicano de Historia del Derecho, XVIII, 2006, pp. 331 - 361. 
(pues en esta categoría no sólo debían contarse las agresiones físicas, sino también las morales) y sin derecho (pues del contrato matrimonial derivaban deberes de fidelidad y el adulterio constituía una falta a esas obligaciones, que no autorizaban la ley o las conveniencias sociales). ${ }^{37}$

En lo anterior, resulta importante un punto: consideraban que el adulterio no se integraba por un acto carnal único. Su postura se ilustra con un caso que data de la etapa en que todavía funcionaba el juicio por jurado, pero cercano a los años que nos ocupan. En 1927 el abogado Federido Sodi defendió a un militar que había asesinado a su esposa y a su amante. Desde mucho antes tenía sospechas de que ella lo engañaba, es más, como demostró el fiscal, tenía elementos para saberlo. Para sorpresa de todos, fue el propio defensor quien orilló al procesado a que confesara que lo sabía: "tenía que matarlo, para remediar no las cosas del pasado, sino para que no se repitieran en el futuro". Lo hizo pues deseaba obtener esa respuesta y mostrar al jurado que el honor no sólo se perdía una vez sino muchas veces, todas aquellas en que el marido era víctima del escarnio público. ${ }^{38}$

Los Ministros y el abogado respondieron así a una de las principales objeciones que se levantaban ante la posibilidad de considerar al uxoricidio por adulterio como un acto cometido en defensa legítima del honor. La defensa legítima se entendía como una acción preventiva. En 1933 José Ángel Ceniceros y Luis Garrido, miembros de la comisión que dos años antes había redactado el código penal y fundadores de la revista Criminalia, consideraron que la muerte de la adúltera no prevenía un daño al honor del marido, pues ya había sido mancillado. ${ }^{39}$ En palabras de otro fundador de la revista, Francisco González de la Vega, "la acción sangrienta del ultrajado se realiza cuando el acto sexual ya está consumado", por ende, la agresión no se prevenía, se vengaba. ${ }^{40}$ Casi al mismo tiempo,

37 Amparo penal directo 3549/31, fecha 21 de abril de 1933. Semanario Judicial de la Federación, Quinta época, Primera Sala, XXXVII, p. 2127.

38 SODI, Federico, El jurado resuelve, $5^{\mathrm{a}}$ ed., México, Porrúa, 2001. (Primera edición 1961). El caso mencionado en pp. 79 - 111.

39 CENICEROS, José Ángel y Luis GARRIDO, "La defensa del honor y el uxoricidio en caso de adulterio", Criminalia, 1933, Año I, pp. 69 - 73. La cita en pp. 69-70.

40 GONZÁlEZ DE LA VEGA, Francisco, Derecho penal mexicano, 34ava edición, México, Porrúa, 2003 (Primera edición 1935), p. 53. 
Ministros de la SCJN negaron la posibilidad de considerar que el marido ultrajado actuara en defensa del honor, "porque la defensa indica evitación, conservación, y ya en este caso el derecho que se defiende no existe, por haber sido violado".

Por tanto, en los primeros años de la década de 1930, aún entre los Ministros de la SCJN, existían posturas encontradas sobre la posibilidad de considerar al homicidio cometido en reacción al adulterio como un acto cometido en prevención a un daño en el honor del cónyuge ofendido. La misma oscilación se nota en decisiones de jueces y Magistrados locales. $^{42}$

La aplicación de la figura de la defensa legítima del honor en casos de uxoricidio cometidos por adulterio se enfrentó a otra objeción. Como mencioné, algunos juristas sostenían que ni siquiera el adulterio femenino constituía un daño al honor del cónyuge. Así lo hizo Carlos Franco Sodi, en 1933, al comentar la obra de Clotario Margalli. Según el comentarista, el cónyuge adúltero podía lastimar el concepto que sobre él mismo se tenía, pero no la visión sobre su cónyuge, pues el honor no podía ser lesionado por actos ajenos. ${ }^{43}$ Lo mismo afirmó, por los mismos años, Francisco González de la Vega. $^{44}$

Si el homicidio por adulterio no podía considerarse como resultado de la defensa legítima del honor, podía recurrirse a la atenuación del acto. Para el individuo que mataba a su cónyuge y/o a su amante sorprendiéndolos en el acto carnal o en uno próximo a él, los redactores del código penal contemplaron una pena menor que para otros homicidas. ${ }^{45}$ Esta reducción ya no estaba justificada en

41 Amparo penal directo 3035/35, fecha 10 de septiembre de 1936. Semanario Judicial de la Federación, Quinta época, Primera Sala, XLIX, p. 1620.

42 Ver SPECKMAN GUERRA, Elisa, "De méritos y reputaciones. El honor en la ley y la justicia (Distrito Federal, 1871-1931)", Op. Cit., y "Los jueces el honor y la muerte. Un análisis de la justicia (Ciudad de México 1871-1931)", Historia Mexicana, LV (220), abril - junio de 2006, pp. $1411-1466$.

43 FRANCO SODI, Carlos, "Libros. La excluyente de defensa legítima del honor, por Clotario Margalli González", Criminalia, septiembre - agosto de 1933, Año I, Nums. 1 - 12, pp. 43-46.

44 GONZÁlEZ DE LA VEGA, Derecho penal mexicano, Op. Cit., p. 52.

45 Código penal de 1931, art. 310. La misma figura estaba contemplada en el código penal de 1871, no en el de 1929, pues los redactores consideraron que cabía en la excluyente de defensa legítima del honor. 
razón del honor, sino a la alteración emocional que podía sufrir el cónyuge cuando se descubría víctima de adulterio. ${ }^{46}$

Por ello, necesitaba tratarse de una sorpresa. Como explicaron en 1935 Ministros de la Primera Sala de la SCJN, la única explicación para la atenuación de la pena aplicable a un "acto tan bárbaro", era la "sorpresa súbita, recibida involuntariamente" y que en ese "ese momento trágico y tremendo" hiriera los sentidos del ofendido con tanta violencia que lo colocara en un estado de "perturbación mental" que le impidiera discernir entre el bien y el mal. Sin embargo, ellos mismos aceptaron una posible ampliación, al considerar que también debía aplicarse cuando el cónyuge descubriera "hechos ejecutados por los responsables de la infidelidad" que demostraran "evidentemente, su relación inmediata anterior o posterior a la copulación. ${ }^{47}$ Un año más tarde la tesis se repitió. Los Ministros sostuvieron que al hablar de sorpresa el legislador no solamente había querido que se tomara en cuenta el elemento objetivo, también el subjetivo. Escribieron: "la actitud de sorpresa implica, por parte del cónyuge inocente, la revelación repentina de un acto de su cónyuge", pudiendo tratarse del descubrimiento de un adulterio existente. ${ }^{4}$

Hasta ahora me he referido al adulterio cometido por la mujer, a su posible daño al honor del marido y a la reacción de éste. Es preciso analizar ahora las posturas existentes frente al adulterio cometido por el esposo.

Enfatizaron los redactores del código penal de 1871: la reputación de la mujer no se empaña por las faltas de su marido. ${ }^{49}$ Existía una "doble moral" o un criterio diferente para el comportamiento de hombres y mujeres. Como apunta la historiadora Francois Carner, a ellas se les exigía preservar su virginidad hasta el matrimonio, guardar fidelidad al marido y permanecer castas durante la viudez; pero a ellos se les permitía sostener relaciones

46 Así lo explicaron dos miembros de la comisión redactora, Ceniceros y Garrido, "La defensa del honor y el uxoricidio en caso de adulterio", Op. Cit., p. 73.

47 Amparo penal directo 4818/34, fecha 26 de febrero de 1935. Semanario Judicial de la Federación, Quinta época, Primera Sala, XLXIII, p. 159.

48 Amparo penal directo 2602/35, fecha 18 de febrero de 1936. Semanario Judicial de la Federación, Quinta época, Primera Sala, XLVII, p. 2684.

49 "Exposición de motivos" del código penal de 1871. 
extramaritales. Escribe la autora: "el honor de la mujer está en sí misma y en el reconocimiento social de su adhesión a las normas, el honor masculino está en sí pero también y sobre todo en el honor de las mujeres de su familia". De ahí que los hombres se vieran lastimados en su honor por el adulterio de su esposa y que, en general, debieran controlar la sexualidad y la conducta de las mujeres de su familia. ${ }^{50}$

Pero además, a las mujeres se le asignaban atributos diferentes que a los hombres, como "sensibilidad, dulzura, intuición, pasividad y abnegación". ${ }^{51}$ No se esperaba de ellas una conducta violenta. Por lo mismo, se pensaba que debían confiar la defensa de su honra a los varones de su familia, legitimándose exclusivamente las acciones que realizaban con el fin de ocultar su deshonra. ${ }^{52}$

Estas ideas se reflejan en los tribunales. Como ejemplo, el juicio de una prostituta, María Villa (a) "La Chiquita" en 1897. La procesada argumentó que había matado a Esperanza Gutiérrez (a) "La Malagueña" en defensa de su honor, pues ella le había arrebatado a dos amantes y se mofaba públicamente del hecho. Argumentó en vano, pues fue condenada como responsable de haber cometido un homicidio calificado. En una entrevista, admitió que no esperaba ser juzgada con el mismo criterio que años antes se había empleado para juzgar al concubino que la había herido al sorprenderla con un amante. Lo explicó considerando que a ella se le había negado la posibilidad de haber actuado cegada por los celos: "a las mujeres como yo, nos juzgan sin corazón, incapaces de sentir un verdadero cariño". ${ }^{53}$ Sería preciso agregar se les juzgaba carentes de honor e incapaces por tanto de defenderlo. En ello coincido con Robert Buffington y Pablo Piccato, quienes afirman que en la mentalidad del

50 CARNER, Francoise. "Estereotipos femeninos en el siglo XIX", en Presencia y transparencia: la mujer en la historia de México, Carmen Ramos Escandón (coord.), México, El Colegio de México, 2006, pp. 99-111.

51 NASH, Mary, "La mayoría marginada: las mujeres en el siglo XIX y primer tercio del XX" en Miguel Izard (compilador), Marginados, fronterizos, rebeldes y oprimidos, Barcelona, Ediciones del Serbal, 1985, pp. 158-174.

52 SPECKMAN GUERRA, "De méritos y reputaciones. El honor en la ley y la justicia (Distrito Federal, 1871-1931)”, Op. Cit., pp. 354-356.

53 Para el proceso, las notas publicadas en el periódico El Imparcial entre el 10 y el 12 de marzo de 1897. Para la entrevista a María Villa, ROUMAGNAC, Carlos, Los criminales en México: ensayo de psicología criminal, México, Imprenta Fénix, 1904, p. 112. 
juez no cabía una mujer defendiendo su honor, pues debía esperar a que lo defendiera un hombre. ${ }^{54}$

En la década de 1930, esta idea conservaba vigencia. Así lo expresaron los editorialistas de Los Tribunales: el honor familiar descansa en la esposa, no en el marido. ${ }^{55}$ Asimismo, muchos de los juzgadores y de los juristas que consideraban que el adulterio manchaba el honor seguían refiriéndose concretamente al cometido por la mujer. ${ }^{56}$ Sin embargo, en estos años la premisa anterior empezó a ser cuestionada. Mencioné que Carlos Franco Sodi argumentaba que el adulterio no dañaba el honor del cónyuge ofendido. En el mismo texto, sostuvo que era necesario dejar de pensar que "una mujer es honrada únicamente cuando ha sabido conservarse virgen". 57

Lo anterior refleja un cambio en la concepción de la mujer y de su honor. Diversas historiadoras se han referido a una transformación en la situación de las mujeres y, a partir de ello, en la concepción de género, tras el movimiento armado. Las mujeres obtuvieron logros jurídicos, se incorporaron a la vida laboral en espacios antes estaban reservados a los hombres y aumentó su presencia en el ámbito educativo y cultural. ${ }^{58}$ Resulta pertinente la afirmación de Mary Kay Vaughan, quien considera que la Revolución "llevó a las mujeres al espacio público de forma nunca antes vista" y trajo consigo "una embestida contra la moral victoriana y las reglas de represión sexual". 59

Varios procesos judiciales permitirían pensar que este cambio en la concepción de la mujer y del honor femenino pudo tener eco en los tribunales. El más famoso fue el de María Teresa Landa, en 1929.

54 BUFFINGTON, Robert y Pablo PICCATO, "Tales of Two Women: the Narrative Construal of Porfirian Reality", The Americas, vol. LV, n. 3, January, 1999, pp. 391 - 424.

55 "Legítima defensa del honor", Op. Cit., p. 110.

56 Por ejemplo, las ya citada tesis de los Ministros de la Primera Sala de la SCJN emitida en 1933 (Amparo penal directo 3549/31) y de los Magistrados del TSJ en 1943 (Sentencia en el proceso de Ersiteo Martínez Loza).

57 FRANCO SODI, “Libros. La excluyente de defensa del honor", Op. Cit, p. 44.

58 Ver, como ejemplo, los trabajos contenidos en la obras coordinada por Gabriela Cano, Mary Kay Vaughan y Jocelyn Olcott, Género, poder y política en el México posrevolucionario, México, FCE, 2010; y en la coordinada por María Teresa Fernández Aceves, Carmen Ramos Escandón y Susie Porter (coordinadoras), Orden social e identidad de género. México, siglos XIX y XX, México, CIESAS - Universidad de Guadalajara, 2007.

59 Mary Kay Vaughan, "Introducción", en Género, poder y política en el México posrevolucionario, Op. Cit, pp. $39-57$. La cita en p. 45. 
La procesada había obtenido el título de "Señorita México" y representado al país en Estados Unidos. Regresó a la Ciudad de México para casarse con un general, mayor que ella. Él era sumamente celoso, le tenía prohibido recibir visitas e incluso leer periódicos. Una mañana rompió la prohibición y vio su imagen en los encabezados, pues la esposa legítima de su marido los acusaba de bigamia. Tomó la pistola del militar para suicidarse, él se lo impidió y entonces le disparó. Su abogado defensor sostuvo que había matado al ver su honor mancillado. El jurado popular así lo admitió. ${ }^{60}$ No fue la única "autoviuda" que en la década de 1920 fue absuelta. De hecho, estas absoluciones sirvieron a los detractores del jurado para ejemplificar sus críticas a la institución que fue suprimida a los pocos días de concluir el juicio de la "Señorita México".

Concetta di Leone fue procesada sólo siete años después que María Teresa Landa. Para entonces, probablemente en respuesta al cambio en la situación de las mujeres y de la concepción de género producida tras la Revolución, existían antecedentes de homicidas que en tribunales habían exitosamente argumentado haber matado en defensa de su honor mancillado por el marido. Sin embargo, el jurado popular había sido suprimido y la princesa ya no sería juzgada por ciudadanos sin formación jurídica, sino por tres jueces con título de abogados quienes, en teoría, serían menos sensibles a sus sufrimientos y a sus encantos, para apegarse a las pruebas y a las leyes.

\section{Los desenlaces}

El juicio estuvo a cargo de los jueces que integraban la Tercera Corte Penal. ${ }^{61}$ El fiscal sostuvo que Concetta di Leone había

60 Ver la obra de Luis de la Barreda, El jurado hechizado. La pasión de María Teresa Landa, México, Porrúa, 2014.

61 Los procesos de primera y de segunda instancia fueron publicados en la revista Anales de Jurisprudencia, Año 1937, Tomo XIX, pp. 693-698. Incluyen los pedimentos y los alegatos de los abogados, las declaraciones de la procesada y de los testigos, los peritajes médicos y 
matado a su esposo por odio y pidió una condena por homicidio simple. No la consideró responsable de un homicidio calificado, a pesar de que podría haber pensado que actuó con premeditación (fue por la pistola a su casa y esperó a que su víctima saliera a caminar), ventaja (estaba armada y él inerme) y alevosía (le disparó por sorpresa, sin darle oportunidad de defenderse ni de evitar el daño causado). ${ }^{62}$

La princesa se hizo representar por un experimentado litigante, José María Gutiérrez. El defensor sostuvo que había actuado en estado de trastorno mental y en defensa de su honor. Es decir, recurrió a dos causas excluyentes de responsabilidad.

Los redactores del código penal no consideraron como responsable penalmente al sujeto que delinquía en un estado de trastorno mental involuntario, de carácter patológico y transitorio. ${ }^{63}$ Para probar que Concetta di Leone así había matado, Gutiérrez ofreció testimonios de amigas y vecinas, quienes sostuvieron que días antes del crimen la habían visto extremadamente alterada y lo atribuyeron al abandono y la miseria. Asimismo, un testigo que había presenciado el asesinato, relató cómo ella le dirigía "palabras amorosas" al cuerpo de Vladimir y aseguró que "parecía haber perdido la razón". Y dos reporteros, Juan J. Barona y "El Güero Téllez", sostuvieron que cuando llegó a la delegación de policía se encontraba en un estado de suma excitación nerviosa y contestaba a sus preguntas con frases sin sentido. ${ }^{64}$

Por otra parte, el abogado defensor solicitó que su cliente fuera examinada por médicos alienistas. Se enfrentó con la oposición de la propia Concetta di Leone, quien le comunicó al juez instructor que jamás dejaría que la llevaran a la Castañeda pues, en esa "casa de

la motivación y fundamentación de las sentencias a los cuales me referiré a lo largo de esta última sección de mi trabajo.

62 La descripción de las calificativas en código penal de 1931, arts. 315-319.

63 Código penal de 1931, art. 15, fracción II.

64 Las declaraciones de los testigos fueron reproducidas en los periódicos Excélsior ("Declaraciones en un proceso", 15 de diciembre de 1936, Segunda sección, pp. 1 y 3; "Ahora resultan con que la princesa está loca", 15 de diciembre de 1936, Segunda Sección, pp. 3 y 18; y "Concetta fue careada ayer", 16 de diciembre de 1936, Segunda Sección, p. 1) y La Prensa ("La princesa Concetta en voz baja habló de la tragedia de su vida", 15 de diciembre, pp. 2 y 9; y "La bella Concetta di Leone fue careada ayer con su íntima amiga", 16 de diciembre, p. 2). 
orates", posiblemente perdería sus facultades mentales. ${ }^{65}$ Además, los médicos nombrados por el fiscal la calificaron como una mujer de constitución mental psicopática de tipo hiperemotiva y negaron que se tratara de una psicópata, y sostuvieron que al matar se encontraba en un estado de excitabilidad exagerada y no en un estado patológico de inconsciencia. ${ }^{66} \mathrm{La}$ defensa por enajenación mental no prosperó.

Tuvo mayor peso el argumento relativo a la defensa del honor. Sostuvo José María Gutiérrez que su defendida, al ser abandonada, había tratado de "atraer al esposo por cuantos medios tuvo a su alcance". Sus intentos sólo le sirvieron para descubrir que su marido tenía una relación amorosa con Xenia Prochorova, con lo cual, "su honor en el sentido social, o sea entendido como la suma de respetos, estimaciones y consideraciones que la propia señora había sabido conquistarse, sufrió una aguda agresión de carácter actual, violenta y sin derecho". Habló de un honor social, en el mismo sentido que penalistas como Mariano Ruíz Funes, José Ortiz Tirado y Alfonso Teja Zabre, se habían referido al "honor objetivo" o al "yo social".

José María Gutiérrez finalizó su "kilométrico alegato" con otra estrategia: sostuvo que la justicia debía atender a la costumbre y escuchar a la sociedad. De hacerlo así, los jueces de la Corte Penal deberían absolverían a la procesada. Al respecto escribió:

Casos como el presente, jamás han sido castigados con una de las más altas penalidades del homicidio. El sentimiento público, reflejado por medio de sus órganos, como son el jurado popular, la prensa, el comentario libre, etc., siempre ha sentido piedad y ha sabido

65 Ver en La Prensa, “Concetta está loca? Esto lo definirán los facultativos”, 23 de enero de 1937, p. 2; y "Concetta no quiere que la juzguen loca", 4 de febrero de 1937, pp. 2 y 21.

66 Las conclusiones de los peritos pueden verse también en "Concetta di Leone no está loca”, La Prensa, 11 de mayo de 1937, p. 12. 
perdonar a quienes matan en las condiciones en que lo hiciera Concetta. ${ }^{67}$

No sólo hizo referencia a veredictos del jurado popular, también a sentencias posteriores. Sostuvo que, sobre todo a partir de 1931, los tribunales habían aplicado en esos casos "las penas más atenuadas de las lesiones y del homicidio, con una forma tan benigna, que nos permite afirmar que en vez de castigar a sus autores, les hace admoniciones que les permiten salir desde luego en libertad y enmendarse en lo venidero".

Solicitó que el crimen pasional de Concetta di Leone fuera considerado como un homicidio cometido en estado de trastorno mental o en defensa legítima del honor (y que la acusada fuera absuelta) o que en su defecto se le considerada un uxoricidio cometido en razón al adulterio (mereciendo una pena que podía ir entre 3 días y 3 años de prisión). ${ }^{68}$

A escasos ocho meses de haber iniciado el juicio, los jueces de la Tercera Corte Penal llegaron a un acuerdo. En su opinión y, conforme al peritaje presentado por el fiscal, no podía considerarse que Concetta di Leone hubiera actuado en estado de enajenación mental. Tampoco en defensa de su honor, pues al igual que otros juzgadores (se refirieron a la tesis de los Ministros de la SCJN emitida en 1933) y juristas (Francisco González de la Vega o Carlos Franco Sodi), pensaban que el adulterio no afectaba el honor del cónyuge ofendido. Por último, rechazaron la posibilidad de aplicar la figura de uxoricidio atenuado, pues adujeron que, según establecía el código penal, sólo podía aplicarse al cometido en el momento en que el homicida sorprendía a su cónyuge sosteniendo relaciones sexuales con su amante. Con ello se separaban de la opinión de Ministros de la Primera Sala Penal de la SCJN, que emitieron en tesis publicadas en 1935 y 1936 (y mencionadas arriba).

67 "Clemencia para Concetta cuyo crimen se juzga solo como un drama de intensa demencia" y "Delitos semejantes no han tenido sentencia contra sus autores", La Prensa, 24 de junio de 1937 , pp. 8 y 19

68 Código penal de 1931 , arts. 16 y 60. 
Consideraron que se había tratado de un homicidio simple pero, en atención a las características de la procesada y a las circunstancias en que había cometido el delito, aplicaron el mínimo de la pena: ocho años de prisión. ${ }^{69}$ "No puedo, no puedo, déjenme. Ocho años. No los resisto. Es toda una vida", exclamó la princesa al ser notificada. ${ }^{70}$

En una entrevista concedida a los reporteros, José María Gutiérrez volvió a referirse a la necesaria contemplación de la costumbre y del sentir social en la justicia. Lamentó que, por primera vez en la ciudad de México, un homicida que había reaccionado a la infidelidad de su cónyuge hubiera sido condenado. Supuso que los jueces habían tomado esa determinación con el fin de deslindarse de los "vicios y debilidades que se le atribuían" al juicio por jurado. Creía que con ello, en lugar de hacerle un favor al nuevo sistema de justicia, estaban cultivando la añoranza por la participación ciudadana en la impartición de justicia. Seguro de que la sociedad no estaría de acuerdo con su decisión, afirmó que surgiría "un clamor unánime a favor del jurado popular". ${ }^{71}$

Introdujo el recurso de apelación. En la sentencia emitida dos meses más tarde, los Magistrados del TSJ argumentaron que no era factible considerar que Concetta di Leone había asesinado en estado de enajenación mental ni en defensa legítima de su honor. Para lo segundo, aportaron tres argumentos. Sostuvieron que el adulterio no constituía una agresión al honor y se apoyaron en José Ortiz Tirado y Alfonso Teja Zabre. La idea estaba ganando peso entre juzgadores y juristas. En segundo lugar, adujeron que el daño que pretendía evitarse podía haber sido posteriormente solucionado por otros medios legales: la denuncia penal del adulterio y el divorcio. Por último, creyeron que al contemplar la figura de uxoricidio atenuado por adulterio, los redactores del código penal habían puesto en claro

69 La sentencia fue publicada en los diarios, por ejemplo, "Concetta di Leone fue condenada a ocho años", La Prensa, 23 de julio de 1937, p. 12.

70 "Concetta di Leone pretende a toda costa arrancarse la existencia", Excélsior, 24 de julio de 1937, Segunda Sección, p. 1.

71 "Concetta di Leone pretende a toda costa arrancarse la existencia", Excélsior, 24 de julio de 1937, Segunda Sección, p. 6. 
que no podía considerarse dentro del excluyente por defensa del honor.

Sin embargo, a diferencia de los jueces de la Tercera Corte Penal, creyeron posible aplicar la figura del homicidio atenuado por adulterio. Para ello se apoyaron en una tesis de la SCJN, en la cual los Ministros sostenían que la sorpresa no podía referirse exclusivamente al descubrimiento de la mujer y de su amante al momento del acto carnal o en uno próximo a él, sino que podía ampliarse al descubrimiento de la existencia misma del adulterio. Lo interesante es que, en este punto, se refirieron a la tarea de los juzgadores, aún más, reivindicaron la tarea de los juzgadores, considerando que éstos no debían limitarse a aplicar mecánicamente el precepto legal, sino que debían interpretarlo para buscar el sentido que había deseado darle el legislador. Para ellos, quedaba claro que los redactores del código penal deseaban atenuar el homicidio cometido por el cónyuge en un estado de ofuscación generado por la constatación de un adulterio, y que la tarde del homicidio, tras ver a su esposo entrar furtivamente en la vivienda y constatar que tenía amoríos con la propietaria, Concetta di Leone se encontraba en dicho estado. Al gradar la sanción tomaron en cuenta características de la procesada: su "condición femenina, educación, ilustración y temperamento romántico", y por otra parte, su peligrosidad mínima y sus altas posibilidades de rehabilitación. Impusieron dos años de prisión. La condena le permitió obtener la libertad condicional. ${ }^{72}$

Excélsior y de La Prensa publicaron y comentaron la sentencia. Sus redactores sostuvieron que los Magistrados habían seguido "la línea trazada de antemano en casos análogos, o sea, de homicidios netamente pasionales", y optado por imitar al jurado popular y mostrarse compasivos "con ese tipo de delincuentes". ${ }^{73}$ Por ende, no atendieron a la posibilidad de interpretar la ley de diversas

72 Expediente carcelario de Concetta di Leone, en AHDF, Fondo Cárceles, Penitenciaría, Expedientes de reos 1920-1949, Caja 331, Partida 6408, Ingresó el 2 de diciembre de 1936.

73 "Concetta Leone es perdonada y deja la cárcel”, Excélsior, 7 de octubre de 1937. Segunda Sección, pp. 1 y 8; y "Concetta saldrá hoy en libertad", La Prensa, 7 de octubre de 1937, p. 2. "Condicionalmente libre, la princesa Nigeradse salió ayer de su celda", Excélsior, 8 de octubre de 1937, Segunda sección, pp. 1 y 8; y "De Wally Simpson ya nadie se acuerda y mi caso es igual", La Prensa, 8 de octubre de 1937, pp. 8 y 17. 
maneras, sino que supusieron que, al igual que los jueces legos, los profesionales habían atendido a factores que, como la costumbre, en cierta forma eran ajenos al hecho juzgado.

La sentenciada lo interpretó de otra forma: "Fue necesario que mi proceso llegara a manos de jueces de edad, estudiosos, para que comprendieran mi tragedia". En la misma declaración, manifestó su renuencia a mirar al pasado. A Xenia Prochorova, "le deseaba felicidad, ya que ella había tronchado la suya". En cuanto al futuro, declaró que permanecería en México, que no volvería a casarse, que seguiría siendo princesa: al igual que de la señora Simpson nadie se acordaba pues todos la señalaban como la duquesa de Windsor, a ella nadie la conocía ya como la señora di Leone. ${ }^{74}$

\section{Reflexiones finales}

Concetta di Leone seguía presentándose a sí misma como protagonista de una novela romántica. El cambio en la situación y la concepción de la mujer, permitieron que las relaciones adúlteras que sostuvo con el príncipe mientras estaba casada con Juan de Velasco, su divorcio, e incluso el hecho de permanecer al lado de su nuevo marido antes que defender a sus hijos y seguirlos cuando abandonaron su casa, no determinaron ni mermaron su imagen. Tuvieron más peso otros aspectos. Poseía los atributos que se esperaban en una mujer y no cuestionaba el papel que en la pareja y la sociedad se le asignaban. Ello impidió que, a pesar de su crimen, se convirtiera en blanco del temor, presente en la sociedad, por la transgresión femenina y, en general, por las consecuencias que podían traer al matrimonio y a la familia la creciente incorporación de la mujer al ámbito público y las demandas de los grupos feministas. Había matado por amor y en defensa de su matrimonio. Todo se le perdonó por su desesperación, su fragilidad, su pasión y su encanto.

74 "De Wally Simpson ya nadie se acuerda y mi caso es igual", La Prensa, 8 de octubre de 1937 , pp. 8 y 17. 
La princesa cumplía con las exigencias tradicionales, pero gozó de licencias modernas. El cambio en la situación de la mujer y en su concepción, también concedió flexibilidad a las leyes que regulaban al homicidio por adulterio $\mathrm{y}$, sobre todo, a su interpretación. Figuras que antes se reservaban a los hombres, como matar en defensa del honor o caer en un estado síquico de profunda alteración ante el descubrimiento del adulterio, ahora podían extenderse a las mujeres.

Los juzgadores estaban, entonces, ante nuevas ideas y valores, y ante novedosas interpretaciones de las leyes. Sus resoluciones fueron variables y la diferencia no puede explicarse de forma simplificada y atendiendo, tan sólo, al cambio en el sistema de justicia. El abogado José María Gutiérrez marcó una línea tajante entre jurados que atendían a las pasiones humanas, la costumbre y la opinión de la sociedad, y jueces profesionales que se alejaban de ellas. Presumiblemente, se limitarían a vincular hechos probados con leyes correspondientes. El análisis del caso de Concetta di Leone no permite apoyar esta radical diferenciación. Cabe recordar lo que señalaron los propios Magistrados del TSJ, quienes afirmaron que la tarea de juzgar iba más allá de la aplicación mecánica de normas en su sentido literal y que exigía la interpretación. En general, los juzgadores involucrados en el caso dieron valor a la costumbre y cabida a sentencias previas, aludieron a opiniones y a códigos éticos, y prestaron atención al aspecto emocional (no sólo porque el estado síquico del cónyuge justificaba la reducción de la pena contemplada para el homicidio por adulterio, también lo hicieron al determinar la sanción y como atenuante secundario consideraron el temperamento romántico de la procesada). No resulta posible saber si en su decisión pesó la opinión expresada en la prensa. El hecho de que la nota roja ya estuviera centrada en la fase anterior al juicio no exige pensar que ya no influía en el juicio, pues lo importante era la previa construcción de la imagen del procesado.

Resulta posible adelantar otras conclusiones. A los jueces de Concetta di Leone, el fiscal y el defensor les ofrecieron la posibilidad de considerar homicidio simple, causas excluyentes y atenuación del homicidio por adulterio, y en consecuencia, de imponer entre tres días y trece años de prisión. Así, el proceso muestra la posibilidad de aplicar a un hecho diversas normas que pueden ser interpretadas de 
varias maneras, y la imposibilidad de considerar que la justicia está exenta de, al menos, cierta dosis de discrecionalidad. También resulta claro que el caso se ubica entre concepciones encontradas del honor y la mujer, o de la justicia y los elementos a considerar por parte de los jueces, así como entre diversas tendencias judiciales. Las resoluciones de primera y segunda instancia se identifican con una tendencia que permanecería, a saber, la imposibilidad de considerar al adulterio como una mancha al honor del cónyuge ofendido y al homicidio por adulterio como un acto cometido en su defensa. Sin embargo, la sentencia final no representa a la corriente que se impondría con el tiempo, pues al paso de los años se negó la posibilidad de extender la sorpresa al descubrimiento del adulterio y se limitó al hallazgo del cónyuge en el momento mismo en que sostenía relaciones sexuales con su amante.

RECEBIDO EM: 15/05/2016 APROVADO EM: 20/06/2016 